\title{
Impact of E-Government on Transaction Cost and FDI Inflows: A Proposed Conceptual Framework
}

\author{
Muhajir Kachwamba \\ Faculty of Social Sciences, University of Agder \& Mzumbe University \\ P.O box 32, Morogoro, Tanzania \\ Tel: 255-712-938-577Ｅ-mail: muhajir.a.kachwamba@uia.no
}

Received: May 10, 2011

Accepted: July 4, $2011 \quad$ Published: November 1, 2011

doi:10.5539/ijbm.v6n11p285

URL: http://dx.doi.org/10.5539/ijbm.v6n11p285

\begin{abstract}
Although vast normative e-government literature supports the assertion that implementation of e-government reduces transaction cost and promotes Foreign Direct Investment; empirical evidence to support this thesis is limited. Even more, there is limited attempt when studying this phenomenon to integrate e-government literature with other literatures in which major constructs of interest are rooted. This article contributes to reducing this gap by establishing a conceptual framework that integrates e-government literature, International Business and Economics literatures as the main fields from which major constructs of interest are grounded. Three Propositions are generated as a guide for a systematic empirical investigation of the phenomenon.
\end{abstract}

Keywords: E-government, Transaction cost, FDI, Investment environment, Cost of doing business

\section{Introduction}

There is a growing large body of literature favouring the argument that adoption of Information Communication Technologies (ICT) such as e-government, reduces transaction cost and promotes Foreign Direct Investment, e.g. (Brown, 2009; Esteves \& Joseph, 2008; Gani \& Sharma, 2003; Gholami, Tom Lee, \& Heshmati, 2006; Lau, 2005; Ojha, Palvia, \& Gupta, 2008). However, such anecdotal arguments lack systematic and logical theoretical linkages from the fields of International Business and Institutional Economics where the constructs of interest are rooted. Hence, the impact of ICT and the relationship proposed may be perceived to be true axiomatically (Bedia, 1999). Nevertheless, vast amount of normative literature and some empirical studies support the argument that ICT (e.g. e-government) has impact on transaction cost and Foreign Direct Investment.

The basic premise of the argument is that successful adoption of ICT particularly Internet can simplify accessibility of commercial and political information that was previously unavailable or hardly restricted by economic actors (Gholami, Tom Lee, \& Heshmati, 2006). In this regard, ICT lowers transaction cost of foreign investors by improving their access to information on various investment opportunities (Addison \& Heshmati, 2004; Lozada \& Fishler, 2005). Based on this view, ICT particularly Internet has the power to sufficiently offer opportunities for public and private information accessibility which ultimately may reduce uncertainty and liability of foreignness (de laTorre \& Maxon, 2001; Ojha, Palvia \& Gupta, 2008). Similarly, in a specific application of ICT in the public sector; electronic government (e-government) may have positive impact on other variables which impede foreign investors in developing countries, e.g.; improving the efficiency of the public administrations and reducing bribes in business transactions (Buss \& Karkowski, 2005; Ojha et al., 2008). From this perspective, developing countries may exploit the opportunities of ICT to reduce uncertainties and information costs facing foreign investors during their start ups period.

Despite the efforts of previous authors, there is still lack of theoretical framework on why the expected relationship should exist. As noted by some authors, most e-government studies suffer from theory usage and testing (Grönlund, 2010; Heeks \& Bailur, 2007). Therefore, most previous authors have established arguments based on ICT literature alone and leave aside other crucial complementary literatures from which the main constructs are originated. In order to get a clearer understanding of the impact of e-government on transaction cost and Foreign Direct Investment; it is imperative to combine both ICT and International Business literatures. This article strives for reducing this gap by integrating both e-government and International Business literatures to develop a grounded theoretical framework that would give a logical flow of arguments on why the relationships should be expected and propositions derived. Specifically, the paper intends to develop a theoretical framework guided by the Institutional theory and OLI framework with a particular focus on the Location advantages to show the impact of e-government on host country institutions. After this introductory section, the paper proceeds as follows. In section 2, I discuss the meaning of key concepts before presenting the theoretical framework. In this section, the literature is reviewed and a summary on some constructs of International Business models which are likely to be influenced by ICT is presented. Section 3 is a brief discussion on the conceptual framework. Section 4 is a concluding remark. 


\section{Key Concepts and Theory}

This section first presents the meaning of Foreign Direct Investment, Transaction Cost and E-government as they are applied in the context of this paper. Then, the theoretical framework is presented and propositions generated.

\subsection{Key Concepts}

There are three key concepts which are important for understanding meaning and their application in this paper. These concepts are: Foreign Direct Investment (FDI), Electronic Government (E-Government) and Transaction Cost.

\subsubsection{Foreign Direct Investment (FDI)}

The efforts to have an international common understanding on the meaning of FDI face challenges due to definitional ambiguity of the concept resulting from the dynamic nature of the phenomenon itself. Parallel to the definitional ambiguity is the measurement problem of the construct (Lipsey, 2001). While traditional Macro-economic Trade theory sees FDI as simply flow of capital from one country to the other; this view, ignores institutional issues surrounding MNEs (Bellak, 1998). The traditional international trade theory assumes, inter alia, competitive markets and immobility of factors of production; but, the reality on the ground is that markets are full of imperfections and factors of productions such as technology and people are mobile (Welch, Benito, \& Petersen, 2007). On the other hand, the economics-based international business literature with a set of theories such as Market imperfections, Transaction cost, Resource based view and OLI framework; do incorporate institutional issues and thus overcome the narrow definition of FDI as simply capital flows (Bellak, 1998; Welch et al., 2007)

The emphasis of this stream of literature is that the key ingredient of FDI is on control rather than capital flows. In that sense, FDI should be regarded as a compact of attributes such as human capital, technology, managerial personnel and goods and therefore incorporates both tangible and intangible resources (Bellak, 1998). One of the popular definitions of FDI is provided by OECD which emphasises that the purpose and motivation of direct involvement by a direct investor in the host country is a strategic long term interest with the enterprise to exert a significant degree of influence on the management of the enterprise (OECD, 1992, 2008). From this broad view of FDI, it suffices to argue that for MNEs to have control over assets and management of enterprise, there is ubiquitous interactions with host country institutions.

\subsubsection{Electronic Government (E-Government)}

Various authors have defined e-government differently and thus, there is no single commonly accepted definition of e-government (Halchin, 2004). The terms used to define e-government appear to be nebulous and therefore may mean different things to different stakeholders (Irani, Al-Sebie, \& Elliman, 2006). For most authors, e-government implies the government's use of Information Communication Technology (ICT) particularly the Internet in delivering services to customers. It implies the utilization of Internet and World-Wide-Web in delivering government information and services to citizens (UN \& ASPA, 2002). E-government also means using information technology especially Internet to improve the delivery of government services to citizens, businesses, and other government agencies (Ojha et al., 2008). From these definitions and due to increasing application of e-government to serve various stakeholders, a distinction between consumer and business focused applications becomes apparent (Awan, 2008). One of the commonly used categorization to reflect the various application of e-government to different customers include Government to Government (G2G), Government to Citizens (G2C) and Government to Businesses (G2B) (Brown \& Brudney, 2001; DeBenedictis, Howell, Figueroa, \& Boggs, 2002). This categorization suggests that governments can offer customized electronic services depending on the type of customers being served. Since the focus is on the impact of e-government on transaction cost and FDI promotion; it is obvious that G2B is the central part of this paper.

It has been argued that Internet applications in the public sector consist of informational and transactional dimensions (Koh \& Prybutok, 2003). Therefore, in the context of International Business, e-government implies use of ICT particularly Internet to provide relevant information to respective investors and transactional services for the purposes of reducing information and bureaucratic costs. The information dimension provides an opportunity for investors to access various information regarding the location especially information on compliance with host country institutions. On the other hand, the transactional dimension allows businesses to interact with governments especially in the application and submission of various forms and permits necessary to comply with government regulations. It is argued that e-government has the potential to reduce the amount of time and money which businesses should spend when complying with government rules and regulations (Eggers, 2004b). Using the informational and transactional dimensions, the author also presents five ways from which e-government can reduce transaction cost of complying with government rules and regulations. These five ways include: 1) providing information in one easy-to access location; 2) simplifying and streamlining reporting requirements; 3) reducing the number of forms; 4) making transactions (paying fees, obtaining permits) easier; and 5) helping businesses understand what regulations apply to them, and how to comply with them.

\subsubsection{Transaction Cost}

Williamson defines transaction costs as the work that individuals or organizations have to put in terms of effort, time and various expenditures in order to obtain relevant information for contract negotiation, bargaining and enforcement (Williamson, 1985). Any cost associated with information search is called ex-ante transaction cost (Brian \& Justin, 1996; Standifird \& Marshall, 2000; Zacharakis, 1997). Similarly, Ex-ante transaction costs can 
be all costs incurred for setting up the business venture and may include negotiation costs, communication costs and other costs of obtaining government authorization and approval for the transaction (Coiera, 2000; Gray \& Jarosz, 1995). Transaction costs can also be categorized as coordination cost and motivation cost, information cost and strategic cost (Coase, 1960; Milgrom \& Roberts, 1992; Natal, 2004). Following Williamson's definition, it is obvious that transaction cost can be conceived as both monetary and non-monetary transaction costs.

As far as Foreign Direct Investments are concerned, foreign investors have to incur some cost prior to business start ups. Since these costs are ubiquitous before business operations, they are considered as ex-ante transaction costs. Making investment abroad in whichever entry mode is one of the risky decisions (Barkema, Bell, \& Pennings, 1996; Johanson \& Vahlne, 1977; Zacharakis, 1997) which requires accumulation of knowledge about the host country environment. Acquiring quality information on local institutions becomes pivotal before committing resources in foreign markets. Both private and public information are relevant for investors' investment decisions (Kinoshita \& Mody, 1999; Loibl \& Hira, 2009; Yeoh, 2000). Investors use public information to acquire knowledge on market size, stocks of infrastructure, costs of running business, foreign investment policies and other host country characteristics (Kinoshita \& Mody, 1999). Valuable information is however costly to obtain and thus information cost is one of such additional costs facing foreign investors which local investors do not necessarily incur. On the other hand, costs of establishing a foreign business in many countries contribute a significant amount of ex-ante transaction especially cost of complying with government procedures and regulations. For example, it has increasingly been argued that the cost of establishing a business in developing countries is high because of unsound Business Environments resulting from excessive bureaucratic procedures, corruption and rent seeking (Kisunko, Brunetti, \& Weder di Mauro, 1999; Morisset \& Lumenga-Neso, 2002).

Therefore, foreign investors face two major ex-ante transaction costs prior to business operations. The first is information cost required to gather all necessary information about foreign markets. The second is entry cost which includes all costs required to comply with government procedures and authorization in starting a particular type of business. Following a definition used in the World Bank Doing Business surveys, entry cost implies all cost related to legal procedures required before a business can officially open its doors (Djankov, La Porta, Lopez-de-Silanes, \& Shleifer, 2002). For host countries, public information accessibility and efficient bureaucratic institutions are indication of good business environment. Among variables of business environment necessary to promote FDI is good governance which include efficient public sector administration, efficient regulation, low corruption and transparency in government (Globerman \& Shapiro, 2003, 2004; World-Bank, 2002).

\subsection{Theory}

It is crucial to note that there is no single theory of FDI and thus variety of theoretical models are used as guides in studying the location decision of multinational firms (Dunning, 2001; Gani \& Sharma, 2003; Isabel, 2009). This theoretical framework is guided by the Institutional theory and OLI framework with a particular focus on one leg; Location advantages (L). Researches on Investment Environment (IE) has combined both Location advantage and institutional perspectives in studying host country business environment particularly in emerging markets (Campos \& Kinoshita, 2003; Gastanaga, Nugent, \& Pashamova, 1998; Hoskisson, Eden, Lau, \& Wright, 2000; Peng, Wang, \& Jiang, 2008) as drivers of FDI. The OLI framework by Dunning (Dunning, 1993, 1998) identifies three distinct advantages as determinants of FDI and MNE activity. The OLI framework or commonly known as 'eclectic theory' posits that a firm interested in FDI activity must have three advantages: Ownership advantage (O) i.e., possession of superior assets over its potential competitors. Internalization advantages (I) i.e., given Ownership advantages, it must be in the best interest for firm to use these advantages itself rather than selling or leasing them through market transactions. Location advantages (L) i.e., Ownership and Internalization advantages should be combined with at least some factor inputs (e.g. natural resources) located abroad (Dunning, 1980; Dunning, 2000; Dunning, 2001). In other words, Foreign Direct Investment occurs because firms possess certain ownership (O) advantages, which they exploit through a process of internalization (I) in countries that offer favourable location (L) advantages (Wint \& Williams, 2002). In this paper, the focus is on the second leg of the tripod; Location advantages.

While location advantages in the host country have traditionally been considered in terms of natural resources especially for developing countries; the trend has shifted towards national host country institutions. National host country institutional regimes are becoming increasingly important as location specific competitive assets (Dunning, 2009). Emphasizing the influence of institutions on firms' activities, Peng argues, 'Since no firm can be immune from institutional frameworks in which it is embedded, there is hardly any dispute that institutions matter' (Peng, 2002). While institutions are increasing regarded as crucial location advantages for a country intending to attract foreign investors, there is still little common understanding among scholars on which institutions matter and why (Bevan, Estrin, \& Meyer, 2004). Some of the host country institutional settings receiving greater attention among scholars are information accessibility and entry bureaucratic regulatory barriers. Why these two institutional variables matter in studying FDI location? This is because lack of information accessibility and excessive regulatory bureaucratic procedures increase cost of doing businesses in the host country and therefore may discourage foreign investment. For example, the low rate of FDI inflows in emerging economies have been associated with both lack of information on business operation and excessive 
bureaucratic procedures in business processes which increase entry cost (Isobe, Makino, \& Montgomery, 2000; Kinoshita \& Mody, 2001; Morisset \& Lumenga-Neso, 2002).

Because of high uncertainty and liability of foreignness in the foreign markets; foreign firms' entry decisions are driven by the accessibility of information in the host country. The uncertainties and information asymmetries facing foreign firms can be reduced by acquiring information. It is noteworthy to mention that information acquisition involves cost; therefore, in a world full of incomplete and asymmetric information, institutions help economic agents to economize on the basis of information and transaction costs (Hoskisson et al., 2000; Mudambi \& Navarra, 2002). Due to high information cost that foreign investors have to incur relative to their counterparts local investors; the location decisions behaviours of foreign firms are informational driven (Goldstein \& Razin, 2006; Mariotti \& Piscitello, 1995). As a location response to the information asymmetry and uncertainties in foreign markets; foreign investors are likely to choose investment locations which offer better access to information in order to minimize their information cost (Azubuike, 2006; He, 2002; Mariotti \& Piscitello, 1995).

On the other hand, recent international experience has shown that excessive administrative procedures required to establish and officially operate a foreign business impede FDI inflows (Morisset \& Lumenga-Neso, 2002). High bureaucratic procedures increase entry cost on the side of investors and is highly correlated with corruption and bribes for government officials (Djankov et al., 2002; Morisset \& Lumenga-Neso, 2002). Less corruption and efficient bureaucratic governments signal for minimal transaction costs to establish businesses and therefore attract Foreign Direct Investment (Campos \& Kinoshita, 2003; Dollar, Batra, \& Hallward-Driemeir, 2001; Gastanaga et al., 1998). There is an increasing recognition among scholars that administrative procedures and the costs (monetary and non monetary) associated with them can influence the location of multinational firms (Dollar et al., 2001).

However, there is a growing literature favouring the argument that Information and Communication Technologies (ICT) can reduce transaction cost, liability of foreignness and uncertainty. The underlying theoretical argument is that development and diffusion of Information Communication Technologies are creating an 'information economy' in which information is among the vital resources and basis for competition (Talero \& Gaudette, 1995). In this regard, the role of Information Communication Technologies is to act as devices which may be used to acquire and process information thereby reducing uncertainties and transaction cost (Addison \& Heshmati, 2004; Bedia, 1999). The basic premise of this argument is that the advent and successful adoption of ICT particularly Internet is said to simplify accessibility of commercial and political information that was previously unavailable or hardly restricted by economic actors (Gholami et al., 2006). For example, Internet is considered as the helpful tool to disseminate and promote investment opportunities (Lozada \& Fishler, 2005) and thus facilitates internationalization process (Danford, 2007, 2008). Similarly, e-government may have positive impact on other variables which impede foreign investors in developing countries, e.g. improving the efficiency of the public administrations and reducing bribes and corruption in business transactions (Ojha et al., 2008). Based on this view, ICT particularly Internet has the power to sufficiently offer opportunities for public and private information accessibility which ultimately may reduce liability of foreignness (de laTorre \& Moxon, 2001). Table 1 summarizes examples of constructs from International Business theories and models of FDI which are likely to be influenced by the increasing global ICT diffusion.

\section{Insert Table 1 - here}

As indicated in Table 1, there is plethora of literature on how ICT can impact various theories and models. The list of these selected constructs is not exhaustive but it provides the theoretical basis of the argument. While most of the arguments are positioned on ICT application in the business sector under the umbrella of E-COMMERCE; the recent literatures suggest that the logical argument applies in the public sector under the umbrella of E-GOVERNMENT. For example, it is argued from the transaction cost perspective that Internet-based sources of information and other online services from the government can help to clarify rules, procedures, process, rights, obligations and responsibilities to the customers e.g.; firms or citizens. This will lead to reduced uncertainty when transacting with the government. Assuming other things being equal, the reduced uncertainty results in low opportunism (likelihood of bureaucrats' rent seeking) and therefore lower transaction cost (bribes) (Ojha et al., 2008). Based on the above theoretical discussion, it is logically suffices to think why ICT becomes among the drivers of FDI. The next part of the literature presents the relationship between constructs with a special application of ICT in the government sector, i.e., e-government to its customers (businesses).

\subsubsection{Relationship between Constructs}

Based on the discussion above, the next step is to show how constructs are related to each other. Since, e-government is a by-product of ICT (Iqbal \& Seo, 2008) the interest is on the relationship between e-government, transaction cost and FDI inflows. In order to clearly elaborate the expected relationship based on the theoretical stance, the propositions are formulated based on two arguments as indicated below.

\subsubsection{Information Cost Argument}

Governments have increasingly been implementing e-government as a tool to reduce both informational and entry costs to foreign investors (Arrunada, 2007; Awan, 2008; Azubuike, 2006; Cho, 2003; Eggers, 2004a, 2004b). There may be two reasons why these countries are increasingly implementing e-government. First, using e-government as their institutional reform efforts to attract FDIs; secondly, as a response to high competitiveness 
for FDI among nations (Mudambi, 1998; Oman, 2000). ICT particularly the Internet is an efficient and effective way to deliver government information, increase transparency and reduce corruption (DiRienzo, Das, Cort, \& Burbridge, 2007; Shim \& Eom, 2008; Yong Hyo \& Byung-Dae, 2004) and therefore reduces search cost and minimize liability of foreignness (de laTorre \& Moxon, 2001; Thompson, Rust, \& Rhoda, 2005). The amount of publicly available information in a particular country influences the pre-entry cost, e.g.; the more public information is accessible, the lower the cost a firm has to pay for own research (Adams, 2006).

In searching for a location at the pre-investment stage, most foreign investors seek information on doing business in the host country including information on required permits, business licenses procedures and labour regulations; information on investment climate conditions including political and economic stability and legal framework; information on costs of doing business in the country including labour costs, property costs and utility costs (Kotler \& Gertner, 2002; UNIDO, 2003). Internet-based sources of information can help firms to acquire this information during the internationalization process (Danford, 2008). Government agencies such as Investment Promotion Agencies (IPAs) in their promotion efforts use Internet marketing to provide this information to investors (Loewendahl, 2001; Lozada \& Fishler, 2005; Lozada \& Kritz, 2007). Investment Promotion Agencies which strive to providing up-to-date, detailed and accurate data (information) on their websites can increase the likelihood of their countries (investment locations) being included in the short list for investment considerations (Harding \& Smarzynska Javorcik, 2007). Therefore, it might be expected that provision of accurate and reliable information on the Internet about the host country business environment is likely to reduce information cost facing foreign investors (Coiera, 2000; Esteves \& Joseph, 2008; Ha \& Coghill, 2008; Savvides, 2006).

Electronic information may improve market functioning by promoting efficient flow of information and thus reduce asymmetric information resulting from market failure (Bakos, 1991; de laTorre \& Moxon, 2001; Lau, 2005; Thomas, Joanne, \& Robert, 1987) by providing one stop opportunity for information access when choosing FDI location (DeBenedictis et al., 2002). Internet has influence on host country location advantage because of reduced transportation cost and distance (both physical and cultural) and liability of foreignness due to increased access to private and public information (de laTorre \& Moxon, 2001). Since information cost is one of the key factors for location choice by Multinational Enterprises (MNEs) (Adams, 2006; Azubuike, 2006; Loibl \& Hira, 2009; Mariotti \& Piscitello, 1995); adoption of e-government is expected to reduce search cost associated with information gathering for FDI location. Consequently, such flow of useful information infrastructure to businesses can attract Foreign Direct Investment (Lau, 2005; Singh, 2003).

\subsubsection{Bureaucratic Institutions and Corruption Argument}

In a similar argument but in a different perspective, Internet increases access to information infrastructure, a necessary condition for transparency and openness thereby reducing corruption and transaction cost in International Business (DiRienzo et al., 2007). Corruption has traditionally been associated with unsound business environment and weak governance structure (Globerman \& Shapiro, 1999; Pajunen, 2008). As a result, corruption is continually becoming one of the important variables of the location advantage (Dunning, 2001; Habib \& Leon, 2002). Therefore, low rate of Foreign Direct Investments inflows in developing countries have been associated with rampant corruption in businesses (Dupasquier \& Osakwe, 2006). A negative relationship between host country institutions and Foreign Direct Investment inflows has been reported in previous studies; (c.f., Habib \& Leon, 2002; Wei, 2000). Accordingly, high level of corruption in host countries shifts ownership preferences towards joint ventures rather than whole owned ventures (Javorcik \& Wei, 2000). E-government adoption ensures easy access to information and so is transparency which implies less corruption (Aubert \& Reiffers, 2004; Iqbal \& Seo, 2008). Recent empirical studies have reported a strong correlation between e-government adoption and corruption (DiRienzo et al., 2007; Pathak, Gurmeet, Rakesh, \& Smith, 2007; Shahkooh, Fasanghari, \& Abdollahi, 2008). E-government can be an effective tool to eliminate all forms of bureaucratic corruption (Bhatnagar, 2003; Pathak et al., 2007) such as bribes in acquiring business permits and registrations which increase business start up cost. Electronic publication of public information increases transparency and openness in transactions with the government; which leads to low opportunism on the side of bureaucrats and hence lower transaction cost such as bribes and delayed time (Ojha et al., 2008).

Apart from Internet-based information, e-government is said to offer other several benefits to investors. Agility has become a common terminology of modern competitive business today and thus time matters for investors. In a country where business entry procedures take excessive time, potential investors are more likely to lose money and hence are willing to locate their investment elsewhere (Morisset \& Lumenga- Neso, 2002). Similarly, bureaucratic institutions and their related costs, e.g.; bribes increase the cost of establishing a foreign business (Djankov et al., 2002; Doh et al., 2003; Kehoe, 1998). E-government offers an opportunity for firms to use online transactions such as applications on business permits, licenses and tax registration (Awan, 2008; Ha \& Coghill, 2008) which reduce entry transaction cost. The ultimate outcome of online transactional services is cost minimization (Awan, 2008; Davidrajuh, 2004) resulting from reduced paper and printing costs; reduced time from frequent visits to government offices moving from one counter to another and avoiding bureaucratic procedures. Costs of bureaucracies e.g.; corruption and bribes are reduced because some of the work of agents (bureaucrats) is substituted by Internet technology (Ojha et al., 2008). Moreover, online transactions can reduce transport and communication costs during contract negotiation and submission of formal entry documents because Internet enabled communication shrinks problems related to geographical distances. 
The major role of e-government transactional services in this sense is to simplify administrative procedures used by governments as regulation of entry. As Heeks (2002) argues, one of the key roles of e-government is to improve the internal performance of the public sector through e-administration. Regulation of entry can be narrowly defined in terms of number of procedures firms must go through, time required to complete a particular official transaction and the cost involved (Djankov et al., 2002). A quality regulatory framework should be efficient in terms of cost, effective in form of clear regulatory and policy purpose, transparent and accountable (Bertok, Beth, Konvitz, Rodrigo, \& Ehlermann-Cache, 2006). Administrative procedures in many countries are excessive and pose burdens to firms particularly in acquiring business licenses and permits. Since time matters for investors in order to benefit from agility strategies such as first mover advantages in markets and innovations; excessive administrative procedures may discourage investments. It has been argued that excessive administrative procedure and their related direct and opportunity cost such as delays in time may negatively influence the location behaviour of MNEs (Dollar et al., 2001).

Accordingly, excessive bureaucratic procedures create rooms for bureaucratic corruption such as bribes in obtaining various government approvals. Such bureaucracies increase costs to firms, can impede market entry, discourage innovation and creates uncertainties for business to quickly respond to new market opportunities which ultimately discourage both domestic and foreign investments (Bertok et al., 2006). According to the World Bank, while it takes 2 days to start a business in Australia, it takes about 215 for the same activity in the Democratic Republic of Congo (World Bank, 2004). With existing intense competition for Foreign Direct Investment, countries with excessive regulatory entry may be more disadvantaged in attracting Foreign Direct Investment compared to their counterparts.

Consequently, many countries have increasingly been adopting and implementing e-government strategies to reduce administrative barriers to investors and thus create favourable investment environment to attract Foreign Direct Investment (Bertok et al., 2006; Mucavele, 2003; World Bank, 2004). From this perspective, e-government can be a tool to create favourable institutional environment in host countries. There is a positive correlation between number of procedures in starting a business in a particularly country and cost involved whereby countries with low number of procedures being successful through implementation of e-government programmes, e.g.; single registration form accessible via Internet (World Bank, 2004). As some authors argue, the implementation of e-government to many countries is expected to reduce entry costs of complying with regulatory procedures and hence attract Foreign Direct Investment (Brown, 2009; Lau, 2005; Morisset \& Lumenga- Neso, 2002; Saidi \& Yared, 2004). These findings, suggest that there might be a relationship between e-government adoption and time necessary to start a business in a particular country. Therefore, efficient adoption of e-government can strengthen the host country institutions which can reduce ex-ante entry transaction cost in starting businesses. This can be interpreted in terms of reduced time, money and efforts such as number of procedures to go through in obtaining business licenses, permits and other business registrations such as taxes. The ultimate outcome of this process will be favourable business environment which will lead to Foreign Direct Investment attraction.

\section{Insert Figure 1 - here}

In summary, figure 1 summarizes the relationship between constructs. Since government information accessibility and inward Foreign Investment are said to be positively correlated (Azubuike, 2006; UNIDO, 2003); then, foreign investors are likely to choose investment locations which offer better access to information in order to minimize their information cost. On the other hand, if corruption discourages Foreign Direct Investment and e-government reduces bureaucratic corruption; then it can be logically argued transitively that e-government adoption and Foreign Direct Investment are related. Therefore, countries with high level of e-government adoption are associated with efficient bureaucratic institutions which lower transaction cost in business start up due to favourable institutional business environments and attractive investment location and thus ultimately expected to promote Foreign Direct Investment. Based on these tenets, three propositions are generated as follows;

P1: E-government adoption and Foreign Direct Investment inflows will be positively related.

P2: E-government adoption and transaction costs will be negatively related

P3: The relationship between E-government adoption and Foreign Direct Investment inflows will be moderated by transaction costs.

\section{Discussion}

The location choice for Foreign Direct Investment involves two types of ex-ante transaction costs. One is information cost and the other is entry cost of complying with government regulatory procedures. In their totality, both increase the cost of doing businesses and thus may impede Foreign Direct Investments. Since uncertainties and information asymmetry in FDI location choice increase information cost (Matambalya \& Wolf, 2001); it is logically suffices to argue that FDI locations are informational driven (He, 2002; Mariotti \& Piscitello, 1995). I have argued in the literature section that as far as the purpose and motivation of direct involvement by a direct investor in the host country is a strategic long term interest with the enterprise to exert a significant degree of influence on the management of the enterprise (OECD, 1992, 2008); then gaining such a control will necessarily imply direct interactions with host country institutions especially in complying with some regulatory requirements. Although governments strive for simplifying these regulatory requirements; there are still 
cumbersome procedures in evaluating and screening FDI projects at the point of entry. The transaction cost in terms of time and money required to obtain various licenses, permits and the approvals needed may be considerable and thus can negatively influence the cost-efficiency of the location (Cho, 2003). Therefore, both costs of information and regulatory entry procedures are important part of ex-ante transaction costs which need to be considered in studying FDI attraction.

It has been argued that diffusion of Information Communication Technologies is an important variable assisting a location to create efficiencies; and therefore becoming a determining factor for FDI attraction (Gani and Sharma). Reciprocating to ICT potentiality, host country governments are increasingly implementing e-government as an innovative institutional tool (Jun \& Weare, 2001) for effective public information accessibility and efficient transparent bureaucratic system. If properly implemented and intelligently used, e-government can help host country governments to create competitive local business environment. This can result from increasing public information access which may reduce investors' search cost; and increasing bureaucratic efficiencies which may reduce costs of bribes and red taps in business transactions (Buss \& Karkowski, 2005). Hence, the proposition on the relationship between e-government and FDI is based on these tenets.

\section{Conclusion}

Studies on the impact of ICT on International business are still limited and even more, few available studies are at the infancy stage in terms of theory development and usage (Grönlund, 2010). Although vast normative literature supports the argument that e-government adoption reduces transaction cost and promotes Foreign Direct Investment; empirical evidence to support such beliefs is needed based on clear theoretical stance. This paper aims at integrating ICT and International Business literature to establish a grounded conceptual framework that would give a logical flow of arguments on why the relationships should be expected. Specifically, the author develops a theoretical framework guided by the Institutional theory and OLI framework with a particular focus on the Location advantages to show the impact of e-government on host country institutions. This article contributes a one step ahead to moving from the theoretical domain towards the empirical realm.

\section{References}

Adams, L. (2006). Public Information, Search Costs and the Location of FDI. [Online] Available: https:/editorialexpress.com/conference/MWIE2007/program/MWIE2007.html (May 15 2009)

Addison, T., \& Heshmati, A. (2004). The New Global Determinants of FDI Flows to Developing Countries: The Importance of ICT and Democratization. In M. Bagella, L. Becchetti, I. Hasan \& W. C. Hunter (Eds.), Monetary Integration, Markets and Regulation: Research in Banking and Finance (Vol. 4, pp. 151-186). Amsterdam: Elsevier. http://dx.doi.org/10.1016/S1567-7915(04)04007-8

Arrunada, B. (2007). Pitfalls to avoid when measuring institutions: Is Doing Business damaging business. Journal of Comparative Economics, 35(4), 729-747. http://dx.doi.org/10.1016/j.jce.2007.08.003

Aubert, J., \& Reiffers, J. (2004). Knowledge economies in the Middle East and North Africa: Toward new development strategies. Washington, DC: World Bank. http://dx.doi.org/10.1596/0-8213-5701-8

Awan, M. A. (2008). Dubai e-Government: An Evaluation of G2B Websites. Journal of Internet Commerce, 6(3), 115 - 129. http://dx.doi.org/10.1300/J179v06n03_06

Azubuike, A. A. (2006). Accessibility of Government Information as a Determinant of Inward Foreign Direct Investment in Africa. Paper presented at the World Library and Information Congress: 72nd IFLA General Conference and Council.

Bakos, J. Y. (1991). A Strategic Analysis of Electronic Marketplaces. MIS Quarterly, 15(3), $295-310$. http://dx.doi.org/10.2307/249641

Barkema, H. G., Bell, J. H. J., \& Pennings, J. M. (1996). Foreign Entry, Cultural Barriers, and Learning. Strategic Management Journal, $17(2), \quad 151-166$. http://dx.doi.org/10.1002/(SICI)1097-0266(199602)17:2<151::AID-SMJ799>3.0.CO;2-Z

Bedia, A. (Ed.). (1999). The Role of Information and Communication Technologies in Economic Development -A Partial Survey. University of Bonn, Discussion Papers on Development Policy, No. 7, July: Center for Development Research.

Bellak, C. (1998). The Measurement of Foreign Direct Investment: A Critical Review. International Trade Journal, 12(2), 227-257. http://dx.doi.org/10.1080/08853909808523905

Bertok, J., Beth, E., Konvitz, J., Rodrigo, D., \& Ehlermann-Cache, N. (2006). Public Governance. In Policy Framework for Investment: A Review of Good Practices: OECD.

Bevan, A., Estrin, S., \& Meyer, K. (2004). Foreign investment location and institutional development in transition economies. International Business Review, 13(1), 43-64. http://dx.doi.org/10.1016/j.ibusrev.2003.05.005

Bhatnagar, S. (2003). The Economic and Social Impact of E-government: A background technical paper for the proposed UNDESA publication -- E-government, the citizen and the state- Debating governance in the information age.

Brown, M. M., \& Brudney, J. L. (2001). Achieving advanced electronic government services: An examination of 
obstacles and implications from an international perspective. Paper presented at the National Public Management Research Conference.

Brown, R. (2009). E-government: Chinese Online Information System Helps Direct Investment Foreign Exchange Business. China Tech News Available http://www.chinatechnews.com/2008/07/25/7038-e-government-chinese-online (Oct 8 2009)

Buss, I., \& Karkowski, H. (2005). eGovernment to improve the local business Environment: A Case Study from Latin America Paper presented at the Reforming the Business Environment conference, Cairo.

Campos, N. F., \& Kinoshita, Y. (2003). Why Does FDI Go Where it Goes? New Evidence from the Transition Economies. SSRN eLibrary.

Cho, J.-W. (2003). Foreign Direct Investment: Determinants, Trends in Flow and Promotion Policies. In Investment Promotion and Enterprise Development Bulletin for Asia and the Pacific (Vol. 1): UNITED NATIONS.

Clemons, E. K., \& Row, M. C. (1991). Sustaining IT Advantage: The Role of Structural Differences. MIS Quarterly, 15(3), 275-292. http://dx.doi.org/10.2307/249639

Coase, R. H. (1960). The Problem of the Social Cost. Journal of Law and Economics, 3(1-44). http://dx.doi.org/10.1086/466560

Coiera, E. (2000). Information Economics and the Internet. Journal of the American Medical Informatics Association, 7(No.3). http://dx.doi.org/10.1136/jamia.2000.0070215

Danford, G. L. (2007). Internationalizing: An information-processing perspective. A study of the level of ICT use during internationalization., Helsinki School of Economics, Helsinki, Finland. http://dx.doi.org/10.1080/08975930802427635

Danford, G. L. (2008). Internet-Based Sources of Information Which Can Be Used to Study the Internationalization Process. Journal of Teaching in International Business, 19(4), 389 - 402. http://dx.doi.org/10.1080/08975930802427635

Davidrajuh. (2004). Planning e - government start - up: a case study on e - Sri Lanka. Electronic Government , an International Journal, 1(1), 92.

de laTorre, J., \& Moxon, R. W. (2001). Introduction to the Symposium E-Commerce and Global Business: The impact of the Information Communication Technology Revolution on the Conduct of International Business. Journal of International Business Studies, 32(4), 617-639. http://dx.doi.org/10.1057/palgrave.jibs.8490988

DeBenedictis, A., Howell, W., Figueroa, R., \& Boggs, R. (2002). E-government Defined: An Overview of the Next Big Information Technology Challenge. Issues in Information Systems, 3(1), 130-136.

DiRienzo, C. E., Das, J., Cort, K. T., \& Burbridge, J., Jr. (2007). Corruption and the role of information. Journal of International Business Studies, 38(2), 320-332, http://dx.doi.org/10.1057/palgrave.jibs.8400262

Djankov, S., La Porta, R., Lopez-de-Silanes, F., \& Shleifer, A. (2002). The Regulation of Entry. The Quarterly Journal of Economics, 117(1), 1-37. http://dx.doi.org/10.1162/003355302753399436

Doh, J. P., Rodriguez, P., Uhlenbruck, K., Collins, J., Eden, L., \& Shekshnia, S. (2003). Coping with Corruption in Foreign Markets [and Executive Commentary]. The Academy of Management Executive (1993), 17(3), 114-129.

Dollar, D., Batra, G., \& Hallward-Driemeir, M. (2001). "Investment Climate and Firm Productivity: India 2000-01", World Bank, mimeo.

Dunning, J. H. (1980). Toward an Eclectic Theory of International Production: Some Empirical Tests. Journal of International Business Studies, 11(1), 9-31. http://dx.doi.org/10.1057/palgrave.jibs.8490593

Dunning, J. H. (1993). Multinational Enterprises and the Global Economy. Wokingham: Addison Wesley.

Dunning, J. H. (1998). Location and the Multinational Enterprise: A Neglected Factor? International Business Studies, 29(1), 45-66. http://dx.doi.org/10.1057/jibs.2008.74

Dunning, J. H. (2000). The eclectic paradigm as an envelope for economic and business theories of MNE activity. International Business Review, 9, 163-190. http://dx.doi.org/10.1016/S0969-5931(99)00035-9

Dunning, J. H. (2001). The Eclectic (OLI) Paradigm of International Production: Past, Present and Future. International Journal of the Economics of Business, 8(2), 173-190. http://dx.doi.org/10.1080/13571510110051441

Dunning, J. H. (2009). Location and the multinational enterprise: John Dunning's thoughts on receiving the Journal of International Business Studies 2008 Decade Award. Journal of International Business Studies, 40(1), 20-34. http://dx.doi.org/10.1057/jibs.2008.75

Dupasquier, C., \& Osakwe, P. N. (2006). Foreign direct investment in Africa: Performance, challenges, and responsibilities. Journal of Asian Economics, 17(2), 241-260. http://dx.doi.org/10.1016/j.asieco.2005.07.002

Eggers, W. (2004a). Boosting E-Government Adoption: A Deliotte Research Publication. Paper presented at the FTA Annual conference. .

Eggers, W. (2004b). Citizen Advantage: Enhancing Economic Competitiveness through E-government. (A 
Deliotte Research Publication) [Online] Available:

http://www.deloitte.com/dtt/cda/doc/content/DTT_DR_CitizenAdv_Sept2004.pdf (Sep 14 2009)

Esteves, J., \& Joseph, R. C. (2008). A comprehensive framework for the assessment of eGovernment projects. Government Information Quarterly, 25(1), 118-132. http://dx.doi.org/10.1016/j.giq.2007.04.009

Furguson, B., \& Keen,J. (1996). Transaction costs, externalities and information technology in health care. Health Economics, $5(1)$ $25-36$. http://dx.doi.org/10.1002/(SICI)1099-1050(199601)5:1<25::AID-HEC181>3.0.CO;2-F

Gani, A., \& Sharma, B. (2003). The Effects of Information Technology Achievement and Diffusion on Foreign Direct Investment. Perspectives on Global Development \& Technology, 2(2), 161-178. http://dx.doi.org/10.1163/156915003322763548

Gastanaga, V. M., Nugent, J. B., \& Pashamova, B. (1998). Host country reforms and FDI inflows: How much difference do they make? World Development, 26(7), 1299-1314. http://dx.doi.org/10.1016/S0305-750X(98)00049-7

Gholami, R., Tom Lee, S.-Y., \& Heshmati, A. (2006). The Causal Relationship between Information and Communication Technology and Foreign Direct Investment. World Economy, 29(1), 43-62. http://dx.doi.org/10.1111/j.1467-9701.2006.00757.x

Globerman, S., \& Shapiro, D. M. (1999). The Impact of Government Policies on Foreign Direct Investment: The Canadian Experience. Journal of International Business Studies, 30(3), 513-532. http://dx.doi.org/10.1057/palgrave.jibs.8490081

Globerman, S., \& Shapiro, D. M. (2003). Governance Infrastructure and US Foreign Direct Investment. Journal of International Business Studies, 34(1), 19-3. http://dx.doi.org/10.1057/palgrave.jibs.8400001

Globerman, S., \& Shapiro, D. M. (2004). Foreign Direct Investment in Emerging and Transition European Countries. [Online] Available: www.bowdoin.edu/ ytang/fdi-europe.pdf (August, 9, 2008)

Goldstein, G. I., \& Razin, A. (2006). An information - based trade off between foreign direct investment and foreign portfolio investment. Journal of International Economics, 70(1), 271. http://dx.doi.org/10.1016/j.jinteco.2005.12.002

Gray, C., W, \& Jarosz, W. W. (1995). Law and the Regulation of Foreign Direct Investment: The Experience from Central and Eastern Europe. Columbia Journal of Transnational Law, 33(1).

Grönlund, A. (2010). Ten Years of E-Government: The 'End of History' and New Beginning. Paper presented at the IFIP International Federation for Information Processing 2010: M.A. Wimmer et al. (Eds.): EGOV 2010, LNCS 6228, pp. 13-24.

Ha, H., \& Coghill, K. (2008). E-Government in Singapore -A Swot and Pest Analysis. Asia-Pacific Social Science Review, 2008.

Habib, M., \& Leon, Z. (2002). Corruption and Foreign Direct Investment. Journal of International Business Studies, 33(2), 291-307. http://dx.doi.org/10.1057/palgrave.jibs.8491017

Halchin, L. E. (2004). Electronic government: Government capability and terrorist resource. Government Information Quarterly, 21(4), 406-419. http://dx.doi.org/10.1016/j.giq.2004.08.002

Harding, T., \& Smarzynska Javorcik, B. (2007). Developing Economies and International Investors: Do Investment Promotion Agencies Bring Them Together? SSRN eLibrary.

He, C. (2002). Information costs, agglomeration economies and the location of foreign direct investment in China. Regional Studies, 36(9), 1029 - 1036. http://dx.doi.org/10.1080/0034340022000022530

Heeks, R. (2002). e-Government in Africa: Promise and practice. Information Polity: The International Journal of Government \& Democracy in the Information Age, 7(2/3), 97.

Heeks, R., \& Bailur, S. (2007). Analyzing e-government research: Perspectives, philosophies, theories, methods, and practice. Government Information Quarterly, 24(2), 243-265. http://dx.doi.org/10.1016/j.giq.2006.06.005

Hoskisson, R. E., Eden, L., Lau, C. M., \& Wright, M. (2000). Strategy in Emerging Economies. The Academy of Management Journal, 43(3), 249-267. http://dx.doi.org/10.2307/1556394

Iqbal, M. S., \& Seo, J.-W. (2008). E-Governance as an anti-corruption tool: Korean Cases. Journal of Korean Association for Regional Information Society, 11(2), 51-78.

Irani, Z., Al-Sebie, M., \& Elliman, T. (2006). Transaction Stage of e-Government Systems: Identification of Its Location and Importance. Paper presented at the System Sciences, 2006. HICSS '06. Proceedings of the 39th Annual Hawaii International Conference on.

Isabel, F. (2009). Determinants of Foreign Direct Investment - A Tale of Nine Theoretical Models. Journal of Economic Surveys, 23(1), 165-196. http://dx.doi.org/10.1111/j.1467-6419.2008.00560.x

Isobe, T., Makino, S., \& Montgomery, D. B. (2000). Resource Commitment, Entry Timing, and Market Performance of Foreign Direct Investments in Emerging Economies: The Case of Japanese International Joint Ventures in China. The Academy of Management Journal, 43(3), 468-484. http://dx.doi.org/10.2307/1556405

Javorcik, B. S., \& Wei, S.-J. (2000). Corruption and Composition of Foreign Direct Investment: Firm-Level Evidence. SSRN eLibrary. 
Johanson, J., \& Vahlne, J.-E. (1977). The Internationalization Process of the Firm-A Model of Knowledge Development and Increasing Foreign Market Commitments. Journal of International Business Studies, 8(1), 23-32. http://dx.doi.org/10.1057/palgrave.jibs.8490676

Jun, K.-N., \& Weare, C. (2001). Institutional Motivations in the Adoption of Innovations: The Case of E-Government. Journal of public Administration Research and Theory Advance.

Kehoe, W. J. (1998). The environment of ethics in global business. Journal of Business and Behavioral Science, 2(Fall), 47-56.

Kinoshita, Y., \& Mody, A. (1999). Private and Public Information for Foreign Investment Decisions. [Online] Available: http://www.cerge.cuni.cz/pdf/wp/Wp150.pdf (Dec 12 2008).

Kinoshita, Y., \& Mody, A. (2001). Private Information for Foreign Investment in Emerging Economies. The Canadian Journal of Economics / Revue canadienne d'Economique, 34(2), $448-464$. http://dx.doi.org/10.1111/0008-4085.00083

Kisunko, G., Brunetti, A., \& Weder di Mauro, B. (1999). Institutional Obstacles to Doing Business: Region-by-Region Results from a Worldwide Survey of the Private Sector. SSRN eLibrary.

Koh, C. E., \& Prybutok, V. R. (2003). The Three Ring Model and Development of an Instrument for Measuring Dimensions of E-Government Functions. Journal of Computer Information Systems, 43(3), 34.

Kotler, P., \& Gertner, D. (2002). Country as brand, products, and beyond: A place marketing and brand management perspective. Journal of Brand Management, $9(4 / 5), \quad 249$. http://dx.doi.org/10.1057/palgrave.bm.2540076

Lau, E. (2005). E-Government and the drive for growth and equity: Science and International Affairs Series Paper. [Online] Available: www.belfercenter.org (Nov 6 2009)

Lipsey, R. E. (2001). Foreign Direct Investment and the Operations of Multinational Firms: Concepts, History, and Data. SSRN eLibrary.

Loewendahl, H. (2001). A Framework for FDI Promotion. Transnational Corporations, 10(1), 1-42.

Loibl, L. C., \& Hira, T. K. (2009). Investor information search. Journal of Economic Psychology, $30(1), 24$. http://dx.doi.org/10.1016/j.joep.2008.07.009

Lozada, H. R., \& Fishler, R. (2005). Marketing a Country: Investment Promotion Agencies and the WWW. European Journal of Economics, Finance and Administrative Sciences, 1(1).

Lozada, H. R., \& Kritz, G. H. (2007). Investment Promotion Agencies on the Internet: Evaluating Promotion Tactics and Web Presence. Journal of International Business Research, 6(2), 17-31.

Mariotti, S., \& Piscitello, L. (1995). Information Costs and Location of FDIs within the Host Country: Empirical Evidence from Italy. Journal of International Business Studies, 26(4), 815-841. http://dx.doi.org/10.1057/palgrave.jibs.8490821

Matambalya, F., \& Wolf, S. (2001). The Role of ICT for the Performance of SMEs in East Africa. Empirical Evidence from Kenya and Tanzania: Discussion Papers on Development Policy No. 42, Center for Development Research, University of Bonn.

Milgrom, P., \& Roberts, J. (1992). Economics, Organizations and Management (International Edition ed.). New Jersey: Prentice-Hall, Inc.

Morisset, J. P., \& Lumenga-Neso, O. (2002). Administrative Barriers to Foreign Investment in Developing Countries. SSRN eLibrary.

Morisset, J., \& Neso, L., Olivier (2002). Administrative Barriers to Foreign Investment in Developing Countries (No. 2848): World Bank Policy Research Working Paper 2848.

Mucavele, G. (2003). Improving the Investment Climate through E-Government and E-Land Registry in Mozambique. Paper presented at the Global Forum on International Investment.

Mudambi, R. (1998). The Role of Duration in Multinational Investment Strategies. Journal of International Business Studies, 29(2), 239-261. http://dx.doi.org/10.1057/palgrave.jibs.8490035

Mudambi, R., \& Navarra, P. (2002). Institutions and international business: a theoretical overview. International Business Review, 11(6), 635-646. http://dx.doi.org/10.1016/S0969-5931(02)00042-2

Nachum, L., \& Zaheer, S. (2005). The Persistence of Distance? The Impact of Technology on MNE Motivations for Foreign Investment. Strategic Management Journal, 26, 747-767. http://dx.doi.org/10.1002/smj.472

Natal, A. (2004). What are transaction cost: In a Birds-Eye. EL COLEGIO MEXIQUENSE. [Online] Available: http://www.cmq.edu.mx/docinvest/document/DN07341.pdf (15.12.2008).

OECD. (1992). Detailed Benchmark Definition of Foreign Direct Investment (2nd ed.): OECD Publications, Paris.

OECD. (2008). OECD Benchmark Definition of Foreign Direct Investment (4th ed.). Paris: OECD Publications.

Ojha, A., Palvia, S., \& Gupta, M. P. (2008). A Model for Impact of E-Government on Corruption: Exploring Theoretical Foundations. In J. Bhattacharya (Ed.), Critical Thinking in E-Governance (pp. 160-170). New Delhi: Gift Publishing. 
Oman, C. (2000). Policy Competition for Foreign Direct Investment: A study of Competition among Governments to Attract FDI: OECD.

Pajunen, K. (2008). Institutions and inflows of foreign direct investment: a fuzzy-set analysis. Journal of International Business Studies, 39(4), 652-669. http://dx.doi.org/10.1057/palgrave.jibs.8400371

Pathak, R. D., Gurmeet, S., Rakesh, B., \& Smith, R. F. I. (2007). E-governance and Corruption-developments and Issues in Ethiopia. Public Organization Review, 7(3), 195. http://dx.doi.org/10.1007/s11115-007-0031-6

Peng, M. W. (2002). Towards an Institution-Based View of Business Strategy. Asia Pacific Journal of Management, 19(2), 251-267. http://dx.doi.org/10.1023/A:1016291702714

Peng, M. W., Wang, D. Y. L., \& Jiang, Y. (2008). An institution-based view of international business strategy: a focus on emerging economies. Journal of International Business Studies, 39(5), 920-936. http://dx.doi.org/10.1057/palgrave.jibs.8400377

Saidi, N., \& Yared, H. (2004). 'e-Government: Technology for Good Governance, Development and Democracy in the MENA Countries'. Working Paper 0304, ERF Working Paper Series.

Savvides, S. C. (2006). The E-Economics of E-Information: "Is The Internet The Great Information Equalizer?" International Journal of Computing \& Information Sciences, Vol. 4 (1).

Shahkooh, K. A., Fasanghari, M., \& Abdollahi, A. (2008). Clustering the Countries According to Relation between E-Government and Transparency. Paper presented at the 3rd International Conference on Information and Communication Technologies: From Theory to Applications

Shim, D. C., \& Eom, T. H. (2008). E-Government and Anti-Corruption: Empirical Analysis of International Data. International Journal of Public Administration, 31(3), 298-316. http://dx.doi.org/10.1080/01900690701590553

Singh, H. (2003). Government in the Digital Era and Human Factors in E-Governance. Paper presented at the Regional Workshop on E-government, Sana'a.

Standifird, S. S., \& Marshall, R. S. (2000). The Transaction Cost Advantage of Guanxi-Based Business Practices. Journal of World Business, 35(1), 21. http://dx.doi.org/10.1016/S1090-9516(99)00032-2

Talero, E., \& Gaudette, P. (1995). Harnessing information for development: a proposal for a World Bank Group vision and strategy. Information Technology for Development, 6(3), 145. http://dx.doi.org/10.1080/02681102.1995.9525267

Thomas, W. M., Joanne, Y., \& Robert, I. B. (1987). Electronic markets and electronic hierarchies. Commun. ACM, 30(6), 484-497. http://dx.doi.org/10.1145/214762.214766

Thompson, V. D., Rust, T. R., \& Rhoda, J. (2005). The Business Value of e-government for small firms. International Journal of Service industry Management, $16(4), \quad 385-407$. http://dx.doi.org/10.1108/09564230510614022

UN, \& ASPA. (2002). Benchmarking E-government: A Global Perspective. New York, UN Publication.

UNIDO. (2003). Africa Foreign Investor Survey 2003: Motivations, operations, perceptions and future plans Implications for investment promotion [Online] Available: http://www.unido.org/fileadmin/import/20146_survey_2003.pdf(March 3 2009)

Wei, S.-J. (2000). How Taxing is Corruption on International Investors? The Review of Economics and Statistics, 82(1), 1-11. http://dx.doi.org/10.1162/003465300558533

Welch, L. S., Benito, G. R. G., \& Petersen, B. (2007). Foreign Operation Methods: Theory, Analysis, Strategy Cheltenham, UK: Edward Elgar Publishing Limited.

Williamson, O. E. (1985). The Economic Institutions of Capitalism: Firms, Markets, Relational Contracting. London: Collier Macmillan.

Wint, A. G., \& Williams, D. A. (2002). Attracting FDI to developing countries: A changing role for government. International Journal of Public Sector Management, 15(5), 361. http://dx.doi.org/10.1108/09513550210435719

World-Bank. (2002). Global Development Finance: Financing the Poorest Countries. Washington, DC: World Bank.

World-Bank. (2004). Doing Business in 2004: Understanding Regulation. Oxford University Press.

Yeoh, P.-L. (2000). Information Acquisition Activities: A Study of Global Start-Up Exporting Companies. Journal of International Marketing, 8(3), 36-60. http://dx.doi.org/10.1509/jimk.8.3.36.19636

Yong Hyo, C., \& Byung-Dae, C. (2004). E-Government to Combat Corruption: The Case of Seoul Metropolitan Government. International Journal of Public Administration, 27(10), $719-735$. http://dx.doi.org/10.1081/PAD-200029114

Zacharakis, A. L. (1997). Entrepreneurial Entry into Foreign Markets: A Transaction Cost Perspective. Entrepreneurship: Theory \& Practice, 21(3), 23-39. 
Table 1. Potential impacts of ICT on some selected International Business (IB) theories

\begin{tabular}{|c|c|l|}
\hline Authors & Theory/Construct of IB & $\begin{array}{l}\text { Selected elements of the } \\
\text { construct driven by ICT }\end{array}$ \\
\hline $\begin{array}{c}\text { (Clemons \& Row, 1991; de } \\
\text { laTorre \& Moxon, 2001; } \\
\text { Ojha et al., 2008) }\end{array}$ & $\begin{array}{c}\text { Transaction Cost/ } \\
\text { Internalization theory }\end{array}$ & $\begin{array}{l}\text { Information cost (search Cost), } \\
\text { Uncertainty Opportunism and } \\
\text { Monitoring cost can be reduced }\end{array}$ \\
\hline $\begin{array}{c}\text { (de laTorre \& Moxon, 2001; } \\
\text { Nachum \& Zaheer, 2005) }\end{array}$ & $\begin{array}{c}\text { Location Advantage and } \\
\text { Distance }\end{array}$ & $\begin{array}{l}\text { Decreasing transport cost, } \\
\text { communication cost and } \\
\text { information cost can shrink } \\
\text { distance (physical, cultural and } \\
\text { institutional) }\end{array}$ \\
\hline $\begin{array}{c}\text { (de laTorre \& Moxon, 2001) } \\
\text { (de laTorre \& Moxon, 2001; } \\
\text { Ojha et al., 2008) }\end{array}$ & Liability of foreignness & $\begin{array}{l}\text { Uncertainty is decreased due to } \\
\text { increased availability of public and } \\
\text { private information }\end{array}$ \\
\hline $\begin{array}{c}\text { Iqbal \& Seo, 2008; Ojha et } \\
\text { al., 2008) }\end{array}$ & Bureacratic institutions and \\
Corruption & $\begin{array}{l}\text { In case of online transactional } \\
\text { services, the duties of the agent can } \\
\text { be reduced or entirely eliminated }\end{array}$ \\
\hline $\begin{array}{l}\text { Information accessibility reduces } \\
\text { uncertainty elimination of } \\
\text { middlemen increases transparency } \\
\text { and hence bureaucratic corruption } \\
\text { may decrease. Agency theory }\end{array}$
\end{tabular}

Source: Author's construct

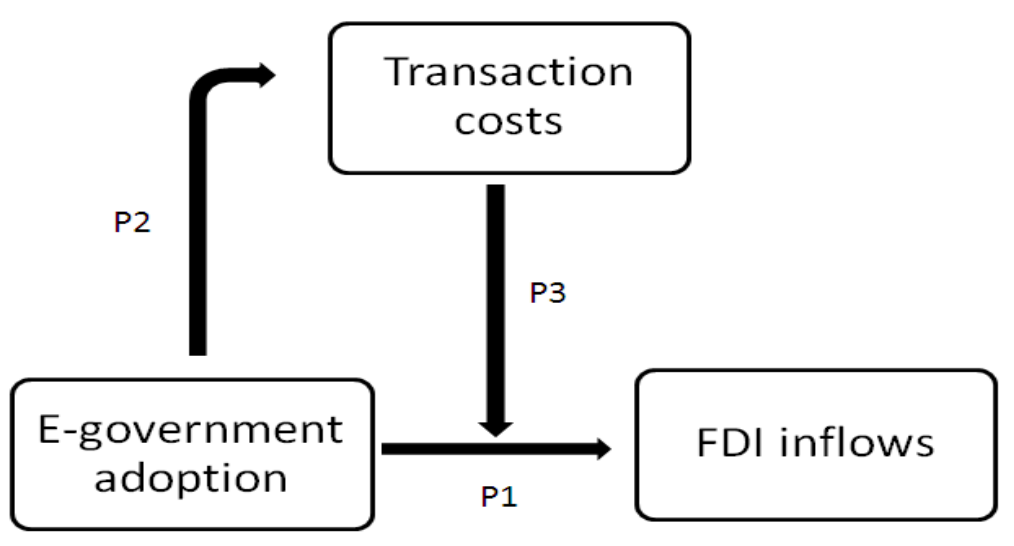

Figure 1. A Proposed Conceptual Model 